\title{
WYBRANE ASPEKTY PARTYCYPACJI PIELĘGNIAREK W KLUBACH FITNESS W KONTEKŚCIE BADAŃ AKSJO-SOCJOLOGICZNYCH
}

\author{
SELECTED ASPECTS OF NURSES' PARTICIPATION IN FITNESS CLUBS IN THE CONTEXT \\ OF AXIO-SOCIOLOGICAL RESEARCH
}

\author{
Grzegorz Konieczny ${ }^{1}$, Renata Rasińska² \\ ${ }^{1}$ Katedra Marketingu i Zarządzania \\ Wyższa Szkoła Hotelarstwa i Gastronomii w Poznaniu \\ ${ }^{2}$ Zakład Organizacji i Zarządzania w Opiece Zdrowotnej \\ Uniwersytet Medyczny im. Karola Marcinkowskiego w Poznaniu
}

DOI: https://doi.org/10.20883/pielpol.2017.35

\section{STRESZCZENIE}

Cel. Celem niniejszej publikacji jest próba przedstawienia wybranych aspektów partycypacji pielęgniarek w ogólnorozwojowych formach aktywności fizycznej oraz zajęciach typu: cardio, cardio\&muscle, muscle, body\&mind oraz rehafit oferowanych przez kluby fitness, jak również próba określenia roli i znaczenia zdrowego stylu życia, którego głównym składnikiem jest aktywność fizyczna w świadomości badanych osób.

Materiał i metody. Badania przeprowadzono w grupie 115 pracujących zawodowo pielęgniarek, w przychodniach lub szpitalach na terenie miasta Poznania za pomocą kwestionariusza ankiety oraz wywiadu narracyjnego. Do analizy uzyskanych wyników wykorzystano metodę statystyki opisowej.

Wyniki i wnioski. Okazuje się, że wśród respondentek istnieje duża wiedza na temat prozdrowotnego stylu życia oraz korzyści wynikających z systematycznego uczestnictwa w szeroko rozumianej kulturze fizycznej, ze szczególnym uwzględnieniem aktywności fizycznej w klubach fitness. W pracy wykazano, że badane kobiety posiadają ogromną wiedzę na temat prozdrowotnego stylu życia oraz doskonałym wzorcem zachowań zdrowotnych. Z narracji respondentek wynika, że teoria na temat prozdrowotnego stylu życia interferuje $z$ ich zachowaniami w czasie wolnym. Taki stan rzeczy wynikać może z wysokiego poziomu wykształcenia medycznego, które implikować może wysoką świadomość korzyści wynikających z prozdrowotnego stylu życia.

SŁOWA KLUCZOWE: pielęgniarki, prozdrowotny styl życia, aktywność fizyczna, fitness, zajęcia: cardio, cardio\&muscle, muscle, body\&mind oraz rehafit.

\section{Wprowadzenie}

Niniejsza praca na temat wybranych aspektów uczestnictwa w zajęciach pielęgniarek fitness wpisuje się w nurt rozważań nauk o kulturze fizycznej. Problematyka niniejszego artykułu wykracza jednak poza obszar tej nauki i jest osadzona w szerszym kontekście, gdyż dotyczy indywidualnych, psychologicznych i społecz-

\begin{abstract}
Aim. The purpose of this publication is to present selected aspects of nurses' participation in general-purpose physical activities, such as: cardio, cardio \& muscle, muscle, body \& mind, and reha-fit activities offered by fitness clubs, as well as the role and importance of healthy lifestyles, the main component of which is physical activity in consciousness of the people surveyed.

Material and methods. The study was conducted in a group of 115 professional nurses, employed in clinics or hospitals in the city of Poznan using a questionnaire survey and a narrative interview. The descriptive statistics method was used to analyze the results.

Results and conclusions. It turns out that among the respondents there is a great awareness of the healthy lifestyle and benefits of systematic participation in broadly understood physical culture, with particular attention to the physical activity taking place in fitness clubs. The study has shown that women are a treasure trove of knowledge about healthy lifestyles and a great role model for health. According to respondents, the theory of a healthy lifestyle interferes with their free-time behavior. This may be due to the high level of medical education that implies high awareness of the healthy lifestyle benefits.
\end{abstract}

KEYWORDS: nurses, pro-health lifestyle, physical activity, fitness, cardio, cardio\&muscle, muscle, body\&mind and reha-fit classes.

nych aspektów życia. Interdyscyplinarny charakter badanego zjawiska tak w płaszczyźnie teoretycznej, jak i praktycznej skłania autorów pracy do wykorzystania wiedzy, twierdzeń i ujęć badawczych typowych dla nauk o kulturze fizycznej, socjologii, psychologii, aksjologii, pedagogiki oraz auksologii. 
Styl życia jest niewątpliwie wypadkową wielu uwarunkowań (m.in. społeczno-kulturowych) oraz świadomych wyborów zdeterminowanych czynnikami psychodemograficznymi.

W opinii Hildt-Ciupińskiej i Bugajskiej najważniejszymi komponentami prozdrowotnego stylu życia są m.in. racjonalne odżywianie, dbałość o ciało, racjonalna gospodarka lekami i suplementami diety, unikanie substancji psychoaktywnych, higieniczny tryb życia (np. odpowiednia długość snu) oraz aktywność fizyczna [1].

Należy w tym miejscu nadmienić, że systematyczna aktywność fizyczna wpływa korzystnie na bilans energetyczny organizmu, powodując pozbycie się nadmiaru tkanki tłuszczowej, a tym samym zapobiega nadwadze i otyłości. Ponadto korzystnie wpływa na stan zdrowia psychicznego człowieka, a przez to sprzyja jego właściwej adaptacji społecznej. Powyższe konstatacje potwierdzają m.in. przedstawiciele Światowej Organizacji Zdrowia, którzy definiując zdrowie podkreślają, że to nie tylko całkowity brak choroby czy kalectwa, ale także stan pełnego, fizycznego, umysłowego i społecznego dobrostanu (dobrego samopoczucia) [2].

\section{Cel pracy}

Podstawą postępowania badawczego w niniejszej publikacji uczyniono dwa cele: teoretyczny i poznawczy. W odniesieniu do pierwszego chodziło o zaprezentowanie szeregu twierdzeń opisowo-wyjaśniających, dotyczących terminu fitness oraz jego form. Z kolei cel poznawczy to opisanie i wyjaśnienie określonego wycinka rzeczywistości społecznej, jakim są w tym przypadku częstotliwość oraz formy uczestnictwa pielęgniarek w ogólnorozwojowych formach aktywności fizycznej oraz zajęciach oferowanych przez kluby fitness. Ponadto w pracy podjęto próbę określenia znaczenia prozdrowotnego stylu życia dla respondentek.

\section{Materiał i metody}

Niniejsza praca ma charakter teoretyczno-empiryczny. Część teoretyczną autorzy pracy oparli na literaturze przedmiotu i obowiązujących w tym zakresie przepisach, co pozwoliło na przedstawienie dotychczasowego stanu wiedzy z analizowanego zakresu. Problematyka badań, dotycząca aktywności fizycznej kobiet, sytuuje się w nurcie badań diagnostycznych, dlatego metodą, za pomocą której gromadzona była wiedza o tym zjawisku, był sondaż diagnostyczny zrealizowany techniką ankiety. Metoda sondażu diagnostycznego dostarcza bogatego materiału badawczego i stwarza duże możliwości interpretacyjne oraz pozwala na gromadzenie wiedzy o masowych zjawiskach społecznych. Równoległe zastosowano - zgodnie z paradygmatem triangulacyjnym - wywiad narracyjny w celu uzyskania bardziej całościowego obrazu i „zminimalizowania zagrożenia odnoszące się do trafności analizy" [3].

Badania przeprowadzono w grupie 115 pracujących zawodowo pielęgniarek, w przychodniach lub szpitalach na terenie miasta Poznania. W wyniku zastosowanej procedury badawczej uzyskano 97 kwestionariuszy ankiet, z czego po weryfikacji ze względu na nieprawidłowe lub niekompletne wypełnienie do analizy zakwalifikowano 88 kwestionariuszy.

\section{Dotychczasowy stan wiedzy}

Kultura fizyczna jest częścią składową rzeczywistości społecznej, a ponadto, jak wykazują dane literaturowe, w ostatnim czasie stała się ona powszechnie akceptowanym priorytetem społeczeństwa globalnego. Współczesna aktywność fizyczna może, a nawet powinna, być zjawiskiem kompensacyjnym wobec współczesnego życia i zagrożeń cywilizacyjnych. Jak zauważa jeden z autorów publikacji, ruch dla człowieka jest najskuteczniejszą „odtrutką biologiczną", kompensującą ujemne skutki obecnych warunków życia [4]. Z kolei Kasperczyk w pracy zatytułowanej „Poziom sprawności i aktywności fizycznej a zdrowie” stwierdza, że ,,aktywność ruchowa to najważniejszy po odżywianiu czynnik determinujący zdrowie. W doskonaleniu autosystemów regulacyjnych organizmu stawiana jest bezsprzecznie na pierwszym miejscu. Jest ona czynnikiem modelującym w sposób najbardziej korzystny stan morfologiczny i funkcjonalny organizmu, a także istotnym czynnikiem kształtującym cechy psychiczne" [5]. Osiński dodaje, że aktywność fizyczna ,,podejmowana systematycznie w istotnym stopniu wpływa na zachowanie, a także umacnianie zdrowia człowieka" [6].

Powyższe konstatacje potwierdza także Matyja, pisząc w jednej ze swych prac poświęconych analizowanemu problemowi, iż celem aktywności fizycznej jest m.in. odbudowa sił psychofizycznych [7] oraz „,poprawa bądź utrzymanie zdrowia i sprawności fizycznej, przy założeniu, że jest on czynnością powtarzającą się" [8].

W ostatnim okresie ukonstytuował się i utrwalił społeczno-ekologiczny model zdrowia, który akcentuje wielość powiązań człowieka z jego środowiskiem. Doskonale obrazuje to mandala zdrowia. Figura symbolizująca wszechświat i miejsce w nim człowieka pokazuje, że zdrowie zależy od wzajemnych powiązań kręgów biosfery i kultury, materialnych i naturalnych środowisk człowieka, zasobów biologicznych, psychicznych i społecznych człowieka oraz różnych form jego aktywności [9].

Od wczesnego dzieciństwa człowiek przejawia naturalną potrzebę ruchu. Ruch jest nieodłącznym elementem naszego życia, naszej egzystencji. Zaniedbania 
w postaci braku nawyku ruszania się, zaowocują w przyszłości. Błędem jest czekanie na dorosłość, by zrozumieć, jakie korzyści niesie ze sobą aktywność ruchowa. Zatem brak w młodym wieku zachęty i warunków do systematycznego zaspokajania tej naturalnej potrzeby, doprowadzi do jej wygaszenia [10].

\section{Podstawowe pojęcia}

\section{Prozdrowotny styl życia}

Odnosząc się do prozdrowotnego stylu życia, należy na wstępnie zaznaczyć, że początek XXI wieku wiąże się m.in. z ogromnym zainteresowaniem problematyką związaną ze stylem życia oraz jej kwalitatywnym wymiarem. Przykładem może być Narodowy Program Zdrowia opracowany na lata 2007-2015. Istotą tego przedsięwzięcia jest „poprawa zdrowia i związanej z nim jakości życia ludności oraz zmniejszenie nierówności w zdrowiu" osiągana przez: kształtowanie prozdrowotnego stylu życia społeczeństwa; tworzenie środowiska życia, pracy i nauki sprzyjającego zdrowiu; aktywizowanie jednostek samorządu terytorialnego i organizacji pozarządowych do działań na rzecz zdrowia [11]. Innym przykładem zainteresowania się prozdrowotnym stylem życia mogą być działania podejmowane przez Europejskie Stowarzyszenie Promocji Aktywności Ruchowej 50+ (ESPAR 50+), którego misją jest budowanie i utrwalanie prozdrowotnych postaw osób dorosłych, czy też promocja zdrowego styl życia przez Towarzystwo Krzewienia Kultury Fizycznej (TKKF).

Prozdrowotny styl życia dotyczy przede wszystkim przyjęcia wzorów świadomych zachowań związanych ze zdrowiem, będących efektem wyborów dokonywanych przez ludzi na podstawie dostępnych, determinowanych ich sytuacją życiową alternatyw [12]. Dokonywane wybory ukierunkowane są na poprawę lub utrzymanie w dobrym stanie zdrowia.

\section{Aktywność fizyczna}

Aktywność fizyczna jest zazwyczaj definiowana jako „dowolna forma ruchu ciała spowodowana skurczami mięśni, przy którym wydatek energii przekracza poziomy energii spoczynkowej”. Ta szeroka definicja obejmuje wszelkie formy aktywności fizycznej, m.in. zawodowe uprawianie sportu czy też rekreację fizyczną [13].

Z kolei „Słownik języka polskiego” (PWN) aktywność fizyczną określa jako „skłonność, zdolność do intensywnego działania, do podejmowania inicjatywy, czynny udział w czymś" [14]. Zaprezentowana definicja odnosi się do aktywności, która jest rozumiana jako proces czy też przejaw pewnych zmian w sensie materialnym, jak i organicznym.

\section{Fitness}

Wolańska pojęcie fitness rozumie jako „ogólną sprawność, wydolność, kondycję psychofizyczną, zdolność przystosowania się, stałą gotowość do podejmowania wysiłków fizycznych" [15]. Powyższa definicja spełnia wszystkie oczekiwania postępu cywilizacyjnego oraz wychodzi im naprzeciw. Pozwala na realizację koncepcji funkcjonowania człowieka w warunkach wymagających elastyczności postępowania poprzez wpływ na ciało w aspekcie czysto fizycznym, jak również poprzez oddziaływanie na umysł i emocje. Ma również spory wpływ na rozwój fizycznej, emocjonalnej oraz umysłowej elastyczności.

Termin „fitness” do 1985 roku utożsamiany był ze słowem „aerobik” pochodzącym od przymiotnika „aerobowy" (tlenowy). Twórcą aerobiku jest Cooper, który jako pierwszy w swojej książce „Aerobics” posłużył się pojęciem „aktywności tlenowej”, odnosząc je do poprawy kondycji osób chorych na serce i kładąc tym samym nacisk na różnorodność ćwiczeń tlenowych, które w efekcie miały wpływać na zachowanie zdrowego serca i układu sercowo-naczyniowego [16]. Cooper założył w Dallas centrum aktywności aerobowej, był jednym z pierwszych zwolenników i liderów ruchu fitness oraz specjalistą od programów treningowych dla kosmonautów. Zaproponowane przez Coopera ćwiczenia rozpropagowane i zmodyfikowane zostały w latach 70. przez Jacky Sarensen, Jane Fondę i Sydney Rome. Własną interpretację ruchu Fonda zaproponowała na kasetach wideo oraz w programach telewizyjnych. Przedstawiła w ten sposób swój styl i sposób prowadzenia zajęć. Judy Sheppard Misset wylansowała natomiast aerobik taneczny. Formami ruchowymi stymulującymi aktywność serca i płuc w czasie wystarczającym do spowodowania korzystnych zmian dla organizmu nazwała aerobik Grodzka-Kubiak [17]. Olex podaje, że aerobik to „ćwiczenia fizyczne przy muzyce, w szybkim tempie, o charakterze tanecznym, ukierunkowane głównie na rozwój wytrzymałości aerobowej oraz siły ćwiczących" [18].

Szymańska przedstawiła klasyfikację uwzględniającą wpływ poszczególnych zajęć na organizm. Zaproponowany przez tę autorkę podział zakłada istnienie dwu podstawowych grup zajęć: kolektywnych przy muzyce oraz aerobowych w siłowni. Na trzy grupy podzielone zostały zajęcia kolektywne przy muzyce. Kryterium tego podziału było uwzględnienie siły oddziaływania na organizm [19].

W kategoriach dobrostanu postrzegane jest współcześnie zdrowie. Ma to niewątpliwie swoje przedłożenie na podejście do sportu. Na przestrzeni czasu zmieniło się znacząco podejście do zdrowia zarówno fizycznego, jak i umysłowego i duchowego. Wskutek tych przemian, 
które znalazły swoje odzwierciedlenie również na rynku fitness, pojawiły się zróżnicowane trendy oraz zaczęto większą uwagę zwracać na potrzeby potencjalnych odbiorców usług oferowanych przez różnego typu kluby oraz na określenie grup docelowych. Klienci fitness również w ostatnim czasie zwiększyli swoje oczekiwania względem klubów, do których chcą uczęszczać. Samo zapewnienie miejsca do praktykowania aktywności fizycznej jest już niewystarczające. Oczekiwania idą w kierunku działań profilaktyczno-zdrowotnych, realizowanych zgodnie ze ściśle określonym planem.

Pojawiające się nowe rodzaje i nazwy form fitness coraz bardziej utrudniają ich klasyfikację. Widoczny jest bardzo dynamiczny rozwój w tej dziedzinie. Nazwy kolejnych form fitness często są pochodną nazw sprzętów i akcesoriów wykorzystywanych do ich wykonania, co jest efektem również w dziedzinie samych sprzętów proponowanych przez firmy zajmujące się ich produkcją.

Nazewnictwo samych form fitness jest bardzo swobodne, czego wyrazem może być używanie różnych określeń do nazwania tej samej formy. Widoczne jest to w przypadku zajęć wzmacniających mięśnie brzucha, bioder oraz ud, które funkcjonują pod następującymi określeniami: ABT, ABF, BPU.

Na pięć głównych grup podzielić można formy fitness proponowane obecnie przez kluby fitness: cardio (koncentrujące się na wzmacnianiu układu sercowonaczyniowego), muscle (nastawione na wzmacnianie mięśni i kształtowanie sylwetki), body\&mind (nastawione na świadomą pracę z ciałem poprzez mentalne pojmowanie ćwiczeń i świadome wykonywanie ruchu), cardio\&muscle (mieszane, łączące dwa cele: kształtowanie wydolności sercowo-naczynowej oraz kształtowanie i wzmacnianie mięśni) oraz rehafit (zajęcia mające charakter prozdrowotny, profilaktyczny i usprawniający).

Anglojęzyczne nazwy form według różnych źródeł podawane są z dużej lub małej litery oraz zawierają człon aerobik. Niektóre formy w nazwie wzbogacone są o termin impact, oznaczający siłę nacisku mierzoną w kilogramach, którą stawy (kolanowe, skokowe, kręgosłupowe i biodrowe) amortyzują podczas ćwiczeń. Wyróżnia się impact wysoki (high) oraz niski (low.) Impact wysoki uaktywnia się podczas biegu, natomiast impact niski przejawia się w marszu. Zajęcia wykorzystujące w znacznym stopniu impact high zdecydowanie bardziej wpływają na obciążenie układu ruchu oraz są bardziej intensywne.

Wzmacnianie wydolności organizmu, rozumianej jako wpływ na układ sercowo naczyniowy oraz oddechowy, jest głównym celem i zadaniem form cardio, posługujących się głównie układami choreograficznymi. Wśród nich wyróżnić należy ich podstawowe formy [20]:
- High impact aerobic - cechą charakterystyczną tych zajęć jest duża ilość podskoków, obrotów i częste zmiany kierunków ruchu. Zajęcia te zaliczane są do najbardziej dynamicznej formy aerobiku. Tempo muzyki, przy której się odbywają, również jest szybkie. Intensywność tych zajęć, niosąca za sobą ryzyko związane z przeciążeniem stawów, powoduje wypieranie ich przez inne formy. Zajęcia te ze względu na dynamikę trwają przeciętnie 45-60 min.

- Low impact aerobic - ta forma jest przeciwieństwem powyższych zajęć. Wolna jest od podskoków. Jedna noga zawsze ma kontakt z podłożem. Charakterystyczną cechą jest powtarzany wielokrotnie układ choreograficzny. Zajęcia te wskazane są dla osób, które nie mogą obciążać aparatu ruchowego. Tempo muzyki tej formy wynosi 126-132 bpm., natomiast tętno ćwiczących powinno mieścić się w przedziale 140-160 ud/min.

- Hilo comb - zajęcia te kształtują wydolność organizmu, pamięć i koordynację ruchową. Forma jest bardzo podobna do low impact. Akcentami wyróżniającymi jest większa intensywność i wyższy stopień komplikacji w zakresie koordynacji. Tempo muzyki wynosi 132-144 bpm., natomiast tętno ćwiczących powinno wynosić 150-170 ud/ $\min$. Zajęcia tego typu trwają $60 \mathrm{~min}$.

- Aeroboxing, kickboxing aerobic, tae-bo, martiancombat - formy łączące ruchy pochodzące ze sportów walki, ujęte w układy choreograficzne. Tempo muzyki wynosi 126-140 bpm.

- Spinning, indor cycling - zajęcia, w których uczestniczyć może każdy bez względu na poziom sprawności. Odbywają się przy użyciu rowerów stacjonarnych. Bardzo intensywne i efektywne przy spalaniu kalorii. Przeprowadzane są pod kierunkiem instruktora przy muzyce. Tempo muzyki wynosi 110-160 bpm. Czas tego typu zajęć to 45-60 min.

- $\quad$ Side - zajęcia odbywają się w oparciu o kroki: łyżwiarski, narciarski i pochodne. Podczas zajęć wykorzystywana jest mata ze specjalnego tworzywa, z ogranicznikami gumowymi przy brzegach. Na buty treningowe zakłada się również specjalne obuwie. Zajęcia trwają 45-60 minut [20].

- Fatburning (spalania tłuszczu) - forma oparta o proste kroki taneczne, z wykorzystaniem na końcu układu choreograficznego. Zajęcia są podobne do low impact. Poziom tętna uczestników powinien być utrzymany na poziomie 120-130 ud/min przez 45-50 min. Zajęcia trwają 60-75 minut [21]. 
- $\quad$ Formy muscle mają za zadanie kształtować sylwetkę, poprawić siłę mięśni, ich elastyczność i kształt. Zajęciami tego typu są: body sculpt/ Shape/Body toning, magic bar, trening izomeryczny oraz formy wzmacniania kolalnego: $A B T /$ ABF/BBS/BPU (wzmacnianie mięśni brzucha, pośladków, ud) [21]:

- Shape/body sculpt/body toning - zajęcia, które wzmacniają wszystkie partie mięśni. Do ich przeprowadzenia wykorzystywane są następujące przybory: hantle, obciążniki na nogi, gumy, piłki. Istnieje możliwość przeprowadzenia tych zajęć również bez przyborów, poprzez pokonywanie oporu własnego ciała. Tempo muzyki wynosi 110-130 bpm. Czas trwania zajęć to 45-60 min [21].

- Magic bar (pump) - ćwiczenia mające na celu doprowadzenie do wzrostu wytrzymałości i siły mięśni bez nadmiernego przyrostu tkanki mięśniowej. Zajęcia odbywają się przy użyciu sztangi o długości 1 metra, z obciążnikami o różnej wadze, zależnej od ćwiczonej partii mięśniowej. Program ten opracowali Nowozelandczycy [21].

- Trening izomeryczny - zajęcia przeznaczone są dla osób o niskiej sprawności ruchowej i słabej kondycji fizycznej, polegają na napinaniu mięśni bez angażowania ruchów w stawach [21].

Z czasem formy ukierunkowane na cel, wpływające np. na zwiększenie masy i siły mięśniowej czy poprawienie wydolności organizmu, zaczęły być wypierane przez nowe, skierowane „do wnętrza”, wyrażone trendem „Body\&Mind”. Ćwiczenia wywodzące się z tego trendu główną uwage koncentrują na świadomości własnego ciała, samoobserwacji oraz wizualizacji. Ćwiczenia te wzmacniają ciało, a jednocześnie wpływają pozytywnie na stan umysłowy i emocjonalny.

Zajęcia nastawione na wzmocnienie układu sercowo-naczyniowego to te znajdujące się w grupie cardio. Efektem udziału w tego typu zajęciach jest podniesienie wydolności organizmu. Do tej kategorii należą następujące formy: low impact, hilo, hip-hop, dance aerobic, latino, fatburning oraz spining. Wzmacnianie mięśni i kształtowanie sylwetki jest zadaniem zajęć z grupy muscle, do której należą: muscle, body pump, ABT, body band. Grupa zajęć bazująca na świadomej pracy ciałem to body\&mind. Wśród form składających się na tę grupę są: pilates, stretching, body art, chi-ball, tai-chi, joga. Cardio\&muscle to grupa zajęć realizująca dwa cele: wzmacnianie mięśni oraz kształtowanie wydolności organizmu. Jest to tzw. grupa zajęć mieszanych. Zajęcia tej grupy to: aerobik tradycyjny, step, TBC, aqua aero- bik, aeroboxing, kickboxing, tae-bo, body Ball. Grupa zajęć prozdrowotnych, czyli rehafit ma na celu działanie profilaktyczne i usprawniające. Do tej grupy należą następujące formy: gimnastyka dla seniorów, ćwiczenia dla osób otyłych, kinderaerbik, rehafit oraz ćwiczenia dla kobiet w ciąży.

\section{Wyniki}

Pierwszym analizowanym elementem w analizie problematyki związanej z partycypacją pielęgniarek w klubach fitness był aspekt związany z komponentami odnoszącymi się do zdrowego stylu życia. Należy stwierdzić, że respondentki posiadają znaczącą wiedzę w tym zakresie. Z ich narracji wynika, że systematyczna aktywność fizyczna (82\% wskazań), zoptymalizowana dieta (racjonalne i regularne odżywianie) (78\% wskazań), dbałość o optymalny czas snu i wypoczynku (41\% wskazań), unikanie lub umiejętne radzenie sobie ze stresem dnia codziennego (35\% wskazań), niekorzystanie z używek (29\% wskazań), racjonalne korzystanie z suplementów diety oraz tabletek ( $28 \%$ wskazań) to podstawowe czynniki konstytuujące prozdrowotny styl życia. Należy nadmienić, że najwięcej wskazań dotyczyło aktywności fizycznej oraz prawidłowego odżywiania. Podsumowując można stwierdzić, że zdrowy styl życia respondentki utożsamiają najczęściej z dwoma powyższymi zmiennymi.

Potwierdzeniem wysokiego poziomu uświadamiania sobie przez badane kobiety potencjału lokującego się w prozdrowotnym stylu życia jest systematyczne podejmowanie aktywności ruchowej. W związku z tym, kolejne pytanie dotyczyło ilości czasu, jaki respondentki przeznaczają na aktywność fizyczną. Okazuje się, że ponad połowa ogółu badanych $(52,0 \%)$ codziennie lub kilka razy w tygodniu korzysta z różnych form aktywności ruchowej w czasie wolnym. Codziennie taką czynność podejmuje 25,0\% badanych pielęgniarek. 12,0\% respondentek wskazuje na kategorię kilka razy w miesiącu. Z kolei 11,0\% kobiet swój wolny czas przeznacza na aktywność fizyczną raz w miesiącu lub rzadziej. W tym przypadku otrzymany wskaźnik jest potwierdzeniem koherencji teorii z praktyką.

Kolejną kwestią w polu badawczym autorów było to, jakie są najpopularniejsze formy aktywności/rekreacji fizycznejpodejmowaneprzezbadanepielęgniarkipozaklubem fitness. Respondentki miały do wyboru 15 dyscyplin, jak również była możliwość podania innej formy, nieujętej w ramach zaproponowanej listy odpowiedzi. Okazuje się, że pośród ogólnorozwojowych form aktywności fizycznej podejmowanych przez respondentki poza klubem fitness najpopularniejsza jest jazda na rowerze oraz nordic walking (odpowiednio: 34,0\% i 18,0\% wskazań). W dalszej kolejności respondentki wskazują na: biegi (14,0\%), gimnastykę i ćwiczenia w 
domu (11,0\%) oraz aerobik (9,0\%). Podobny odsetek (po 7\%) wskazuje dance aerobik oraz pływanie.

Kolejnym niezmiernie istotnym aspektem badań była kwestia uczestnictwa respondentek w jednej z pięciu form fitness, które są dostępne w klubach. Dane wykazują, że respondentki najchętniej podejmują zajęcia z grupy cardio\&muscle (zajęcia mieszane, których zadaniem jest m.in. wzmacnianie mięśni oraz kształtowanie wydolności organizmu) oraz zajęcia z grupy muscle, istotą których jest wzmacnianie mięśni i kształtowanie sylwetki (odpowiednio: 42,0\% i 32,0 \% wskazań). W dalszej kolejności (15,0\%) badane pielęgniarki wybierają zajęcia nastawione na świadomą pracę z ciałem, są to zajęcia typu body\&mind. $11 \%$ kobiet wskazuje na zajęcia cardio, koncentrujące się na wzmacnianiu układu sercowo-naczyniowego. Z kolei na zajęcia typu rehafit, których celem jest profilaktyka i podnoszenie ogólnej sprawność fizycznej, decyduje się $11 \%$ ogółu badanych kobiet.

\section{Dyskusja}

Z narracji badanych wynika, że chętnie wybierane są takie zajęcia jak: aerobik tradycyjny bez choreografii, ABT oraz gimnastyka odchudzająca/fat burning class oraz pilates. Istotą pilates jest odpowiedni dobór ćwiczeń tak, aby wzmacniać wszystkie mięśnie ciała. Szczególną uwagę zwraca się jednak na wewnętrzne mięśnie tułowia. Istotnym elementem jest ułożenie ciała podczas ćwiczeń, co w efekcie ma doprowadzić do świadomego używania mięśni odpowiadających za stabilizację przy wykonywaniu określonego ruchu. Słabe i zaniedbane mięśnie ma kształtować pilates [22]. Forma ta uczy również tzw. napięcia środka (corestability) uwzględniającego mięśnie głębokie brzucha, pośladków, grzbietu oraz miednicy małej. Pilates polega na łączeniu ćwiczeń fizycznych oraz koncentracji umysłu i kontroli oddechu. Jak wskazuje Austin, ,,pilates to program fitness dla umysłu i ciała, który pozwala uzyskać nie tylko wspaniałą sylwetkę, ale także równowagę psychiczną i uczuciową, uspokaja i odświeża" [23].

W ostatnich latach nastąpiło znaczące ograniczenie ilości wysiłku fizycznego koniecznego do wypełnienia domowych obowiązków, do przemieszczania się z miejsca na miejsce, a nawet do podjęcia działalności rekreacyjnej. Wyniki ogólnopolskiego badania NATPOL Plus opublikowane przez Zdrojewskiego wskazują, że jedynie ok. 41\% kobiet i nieco ponad 50\% mężczyzn podejmuje poza pracą jakąkolwiek aktywność fizyczną [24].

Wg CEBOS Polacy podejmują aktywność fizyczną przede wszystkim dla zdrowia (70\%), a trochę rzadziej dla przyjemności (61\%) [25]. Niemała grupa badanych, bo prawie co drugi uprawiający sport, uprawia go dla poprawy samopoczucia, odreagowania stresu, aby być w dobrej formie, zaś dla co trzeciego sport to przede wszystkim sposób wspólnego spędzania czasu ze znajomymi, przyjaciółmi, rodziną. Co czwarty respondent podejmujący aktywność fizyczną deklaruje, że uprawia sport głównie po to, aby dobrze wyglądać, mieć ładną sylwetkę. Wraz z wiekiem pojawia się częściej dbałość o dobrą sprawność i zdrowie.

Okazuje się, że wśród respondentek istnieje duża świadomość potrzeby prozdrowotnego stylu życia oraz korzyści wynikających z systematycznego uczestnictwa w szeroko rozumianej kulturze fizycznej, ze szczególnym uwzględnieniem aktywności fizycznej dokonującej się poprzez zajęcia w klubach fitness. W pracy wykazano, że badane kobiety mają ogromną wiedzę na temat prozdrowotnego stylu życia oraz są doskonałym wzorcem zachowań zdrowotnych. Z narracji respondentek wynika, że teoria na temat prozdrowotnego stylu życia interferuje $z$ ich zachowaniami w czasie wolnym. Taki stan rzeczy wynikać może z wysokiego poziomu wykształcenia medycznego, które implikować może wysoką świadomość korzyści wynikających z prozdrowotnego stylu życia.

$\mathrm{Na}$ podstawie przeprowadzonych analiz badawczych można skonstatować, że uczestniczenie w ogólnorozwojowych formach aktywności fizycznej, w tym w zajęciach oferowanych przez kluby fitness, jest dla respondentek swoistym implikatorem konwersji zachodzących we współczesnym świecie, który Arjun Appadurai określa światem, „globalnych przepływów kulturowych".

\section{Wnioski}

1. Poddając analizie dane uzyskane w wyniku przeprowadzonych badań należy stwierdzić, że zdecydowana większość badanych pielęgniarek posiada wiedzę na temat czynników konstytuujących zdrowy styl życia. Wśród wymienianych składników najczęściej wskazywano na systematyczny udział w aktywności fizycznej oraz prawidłowe odżywianie.

2. Zdecydowana grupa respondentek codziennie lub kilka razy w tygodniu korzysta z różnorakich form rekreacji ruchowej w czasie wolnym.

3. Wśród ogólnorozwojowych form aktywności/rekreacji fizycznej poza klubem fitness, 34,0\% respondentek wybiera jazdę na rowerze, a 18,0\% nordic walking.

4. Spośród zajęć fitness organizowanych przez kluby respondentki najchętniej wybierają zajęcia z grupy cardio\&muscle oraz zajęcia z grupy muscle. 


\section{Piśmiennictwo}

1. Hildt-Ciupińska K, Bugajska J. Rola zachowań prozdrowotnych w promocji zdrowia pracowników. Bezp pr Nauk Prak 2011; 9: 10-13.

2. http://www.seremet.org/who_zdrowie.html (data wejścia: 24.05.2016).

3. Sztumski J. Wstęp do metod i technik badań społecznych. Katowice: Wydawnictwo Naukowe: Śląsk; 1995. 65.

4. Konieczny G. Interdyscyplinarne spojrzenie na rekreację w czasie wolnym. W: Siwiński W. Tauber RD, Mucha-Szajek E. (red.), Teoria i praktyka w dziedzinie hotelarstwa, żywienia, turystyki i rekreacji. Poznań: Wydawnictwo Naukowe Wyższej Szkoły Hotelarstwa i Gastronomii; 2014. 143.

5. Kasperczyk T. Poziom sprawności i aktywności fizycznej a zdrowie. Nowa Med. 12/2000. 121.

6. Bojar I, Wojtyła K, Owoc A. Aktywność fizyczna uczniów szkół podstawowych powiatu miasta Kalisz i powiatu kaliskiego. Med Ogólna 2010; 16 (XLV): 33.

7. Matyja D. Pojęcia sportu i rekreacji- PWN Leksykon - Sport. Warszawa: PWN; 2000. 163.

8. Birch K, MacLaren D. George K.: Fizjologia sportu. Warszawa: PWN; 2009. 14.

9. Napierała M, Żelazna M. Aktywność fizyczna w zdrowym stylu życia nauczycieli szkół ponad gimnazjalnych miasta Koronowo. W: Napierała M, Muszkieta R, Cieślicka M, Żukow W (red.) Zdrowie i rekreacja ludzi w różnym wieku. Bydgoszcz-Poznań: Polskie Towarzystwo Naukowe Kultury Fizycznej, Wyd. Ośrodek Rekreacji, Sportu i Edukacji w Poznaniu, Monografia nr 17/13, 2013. 45-46.

10. www.sportmania.waw.pl] (data wejścia: 12.05.2016).

11. Dziubiński Z. Wartości ciała i kultury fizycznej w filozofii i teologii Jana Pawła II. Wychow Fiz Sport 1986; 3: 109-133.

12. Cockerham W. New directions in lifestyle research Int. J. Public Health 2007;52:327-328.

13. http://ec.europa.eu/assets/eac/sport/library/policy_documents/ eu-physical-activity-guideline (data wejścia: 12.05.2016).

14. Słownik języka polskiego. Warszawa: PWN; 2015.

15. Wolańska T. Leksykon - sport dla wszystkich - rekreacja ruchowa. Poznań: Wyd. AWF; 1997. 82.
16. Cooper K. The new aerobics. New York: M. Evans \&Company ; 1970. 76.

17. Grodzka-Kubiak E. Aerobik czy fitness. Poznań: DDK Editio; 2002.

18. Olex D, Fitness, metodyka i praktyka. Katowice: Górnośląska Oficyna Wydawnicza SA; 2004. 5.

19. Szymańska I. Aerobik czy fitness? Body Life 2003. 148.

20. Por. Eider J. Slide Reebok, W: Aktywność ludzi w różnym wieku. Szczecin: PTNKF Albatros; 1995. 132.

21. Szymański I. Materiały szkoleniowe „Aerobic Personal Training” 1997. 163.

22. Janik B. Pilates, prawdziwa siła od środka. Szczecin: Asz PPH GAMP; 2005. 32.

23. Austin D. Pilates dla każdego. Poznań: Zysk i S-ka; 2002. 4.

24. Zdrojewski T, Bandosz P, Szpakowski P et al. Rozpowszechnienie głównych czynników ryzyka chorób układu sercowonaczyniowego w Polsce. Wyniki badania NATPOL PLUS. Kardiol Pol. 61: IV-5; 2004.

25. Omyła-Rudzka M., Aktywność fizyczna Polaków. Komunikat z badań CBOS. Warszawa 2013, http://www.cbos. pl/SPISKOM.POL/2013/K_129_13.PDF, (data dostępu 2.05.2016).

Artykuł przyjęty do redakcji: 13.06.2016

Artykuł przyjęty do publikacji: 25.08.2016

Źródło finansowania: Praca nie jest finansowana z żadnego źródła. Konflikt interesów: Autorzy deklarują brak konfliktu interesów.

\section{Adres do korespondencji:}

Renata Rasińska

ul. Mariana Smoluchowskiego 11

60-179 Poznań

tel.: 618612254

e-mail: rasinska@ump.edu.pl

Zakład Organizacji i Zarządzania w Opiece Zdrowotnej

Uniwersytet Medyczny im. Karola Marcinkowskiego w Poznaniu 